\title{
PENINGKATAN HASIL BELAJAR MATEMATIKA MELALUI PENGEMBANGAN BAHAN AJAR BERBASIS WEBSITE
}

\author{
Alif Ringga Persada \\ IAIN Syekh Nurjati Cirebon \\ alifringgapersada@syekhnurjati.ac.id
}

\begin{abstract}
At globalization era in this time process the study challenge which big relative, related to technological science growth (Very extraordinary IPTEK). very the fast Growth IPTEK offer to us various amenity in obtaining and mengolah information. Especially vary it study media which can be used by a teacher at the (time) of submitting study items. development of teaching Substance which is is made by by a researcher is substance development teach to base on the Website of at address of web belajarmatematika.id. Intention of this research is : 1)Mengetahui use of study media base on the e-learning (Website) at school 2) Yielding product of study media " being based on Website of at items develop;build to level off 3) Knowing result learn the student use the Website of at items of parallelogram and segita.4) Getting product of multimedia of mathematics study for the student of class 7 High School Pertama.5) Knowing storey;level of elegibility of multimedia of study of mathematics of class student 7 Junior High School of research Method used in this research is Rnd ( Research And Development)Dengan model the ADDIE with the technique of data collecting use the sheet of enquette and tes. Population in this research is entire/all class of VIII SMP Country 1 Krangkeng of Regency Indramayu of while intake sampel use the technique of Purposive Sampling and chosen of class of VIII E as experiment class. Pursuant to data processing result, obtained by result of analysis of enquette of respon student to substance teach to base on the Website show the strong criterion with the mean of equal to 85,08\%. Beradasarkan of result of test of independent sample t test the ( two tailed), knowable that value t_hitung >t_tabel, that is 6,331>2,000. Because t_hitung >t_tabel, hence $\mathrm{HO}$ refused and accept $\mathrm{Ha}$, what its meaning there are difference of result of learning at class of experiment and class control at fundamental of discussion segiempat and trilateral
\end{abstract}

Keyword: Substance Teach The, Website, Result of Learning

\section{ABSTRAK}

Pada era globalisasi saat ini proses pembelajaran menghadapi tantangan yang relatif besar, yang berkaitan dengan perkembangan ilmu pengetahuan teknologi (IPTEK) yang sangat luar biasa. Perkembangan IPTEK yang sangat pesat tersebut menawarkan kepada kita berbagai kemudahan dalam memperoleh dan mengolah informasi. Terutama bervariasinya media pembelajaran yang dapat digunakan oleh seorang guru pada saat menyampaikan materi pembelajaran. Pengembangan bahan ajar yang dibuat oleh peneliti adalah pengembangan bahan ajar berbasis Website pada alamat web belajarmatematika.id. Tujuan dari penelitian ini adalah : 1)Mengetahui penggunaan media pembelajaran berbasis e-learning (Website) di sekolah. 2) Menghasilkan produk media pembelajaran "berbasis Website pada materi bangun datar. 3) Mengetahui hasil belajar siswa menggunakan Website pada materi segi empat dan segita.4) Mendapatkan produk multimedia pembelajaran matematika untuk siswa kelas 7 Sekolah Menengah Pertama.5) Mengetahui tingkat kelayakan multimedia pembelajaran matematika siswa kelas 7 Sekolah Menengah Pertama Metode penelitian yang digunakan dalam penelitian ini adalah $R n D$ (Research and Development)dengan model ADDIE dengan teknik pengumpulan data menggunakan lembar angket dan tes. Populasi dalam penelitian ini adalah seluruh kelas VIII SMP Negeri 1 Krangkeng Kabupaten Indramayu sedangkan pengambilan sampel menggunakan teknik Purposive Sampling dan terpilih kelas VIII E sebagai kelas eksperimen. Berdasarkan hasil pengolahan data, diperoleh hasil analisis angket respon siswa terhadap bahan ajar berbasis Website menunjukkan kriteria kuat dengan rata-rata sebesar 85,08\%. Beradasarkan hasil uji independent sample t test (two tailed), dapat diketahui bahwa nilai $t_{\text {hitung }}>t_{\text {tabel }}$, yaitu 6,331 $>2,000$. Karena $t_{\text {hitung }}>t_{\text {tabel }}$, maka $\mathrm{H}_{0}$ ditolak dan menerima $\mathrm{H}_{\mathrm{a}}$, yang artinya terdapat perbedaan hasil belajar pada kelas eksperimen dan kelas kontrol pada pokok bahasan segiempat dan segitiga.

Kata Kunci: Bahan Ajar, Website, Hasil Belajar 


\section{PENDAHULUAN}

Pendidikan merupakan suatu hal yang penting dalam peradaban manusia. Melalui pendidikan, manusia dapat mengembangkan segala sumber daya yang dimiliki. Menurut UU No. 20 tahun 2003 yang dikutip oleh Sanjaya (2011: 2) tentang sistem pendidikan nasional menyatakan bahwa pendidikan adalah usaha sadar dan terencana untuk mewujudkan suasana belajar dan proses pembelajaran agar peserta didik secara aktif mengembangkan potensi dirinya untuk memiliki kekuatan spiritual keagamaan, serta keterampilan yang diperlukan dirinya dan masyarakat.

\section{Peningkatan}

mutu

pendidikan merupakan hal yang sangat penting dan sentral di negaranegara berkembang seperti di negara kita Indonesia. Berbagai upaya telah dilakukan oleh pemerintah dalam hal meningkatkan mutu pendidikan. Guna meningkatkan mewujudkan cita-cita bangsa. Sumber daya manusia adalah suatu sistem dalam keberhasilan pembangunan bangsa. Salah satu hal yang harus segera ditingkatkan adalah mutu pendidikan bangsa ini, untuk meningkatkan mutu pendidikan dapat dilakukan dengan adanya inovasi dalam pembelajaran seperti, menggunakan alat peraga atau menggunakan media yang lebih menarik minat berlajar siswa. Guru saat ini masih banyak yang menggunakan model pembelajaran yang konvensional hanya dengan ceramah dan memberi tugas saja..

Perkembangan media,
menurut Ashby dalam Umar
(2013:126) telah menimbulkan dua
kali dari empat kali revolusi dunia

pendidikan. Revolusi pertama telah terjadi beberapa puluh abad yang lalu, yaitu pada saatorang tua menyerahkan pendidikan anakanaknya kepada orang lain yang berprofesi sebagai guru, revolusi kedua terjadi dengan digunakannya bahasa tulisan sebagai sarana utama pendidikan, revolusi ketiga timbul dengan tersedianya media cetak yang merupakan hasil ditemukannya mesin dan teknik percetakan, dan revolusi keempat berlangsung dengan meluasnya penggunaan media komunikasi elektronik.

Penggunaan media dalam
proses belajar mengajar tentu memiliki fungsi sebagai alat bantu mengajar untuk mencapai tujuan pendidikan. Penggunaan media pembelajaran yang tepat dapat meningkatkan hasil belajar siswa. Penggunaan media pembelajaran dalam proses belajar mengajar tentu memiliki sebagai alat bantu guru dalam mengajar yang dapat digunakan oleh guru dalam menyampaikan materi pelajaran kepada siswa. Sebuah inovasi dalam pengembangan bahan ajar non cetak untuk meningkatkan hasil belajar siswa salah satunya adalah pembelajaran berbasis website. Pembelajaran berbasis website ini merupakan suatu inovasi dalam dunia pendidikan yang dapat digunakan sebagai media dalam proses belajar mengajar.

\section{Penggunaan} media pembelajaran berbasis website ini sedikit demi sedikit akan menggantikan penyampaian materi dengan metode ceramah, hal ini senada yang diungkapkan oleh Munthoha, dkk (2010:195) menyatakan bahwa perkembangan 
teknologi dalam dunia pendidikan telah menggeser penyampaian materi dengan metode ceramah ke arah penggunaan media pembelajaran. Selain itu, media pembelajaran mengalami perubahan dan perkembangan dari media dalam bentuk buku sampai bentuk audio visual yang ditampilkan dalam jaringan internet yang dapat diakses secara online.

Menurut lembaga riset pasar e-Markerter, populasi pengguna internet di Indonesia mencapai 83,7 juta orang pada tahun 2014, diperkirakan pada tahun 2017 akan mencapai 112 juta orang di indonesia yang akan menggunakan internet, mengalahkan Jepang di peringkat ke-5 yang pertumbuhan jumlah pengguna internetnya lebih lamban. Secara keseluruhan, jumlah pengguna internet di seluruh dunia diproyeksikan bakal mencapai 3 miliar orang pada 2015. Tiga tahun setelahnya, pada 2018, diperkirakan sebanyak 3,6 miliar manusia di bumi bakal mengakses internet setidaknya sekali tiap satu bulan (Sumber : Kominfo.go.id). Hal ini merupakan suatu peluang yang sangat besar terutama dalam dunia pendidikan guna mengembangkan media pembelajaran berbasis website. Banyaknya pengguna internet tersebut memberikan gambaran kepada kita bahwa mayoritas orang mencari informasi sekarang ini melalui internet, dan guru dapat menggunakan media internet untuk meningkatkan hasil berlajar siswa melalui media pembelajaran yang menarik.

Atas dasar tersebut, diperlukan pengembangan bahan ajar berbasis Website untuk membantu siswa dalam mempelajari materi, sehingga siswa dengan mudah memahami materi yang disampaikan dan tercapainya tujuan pembelajaran secara maksimal. Dengan demikian, peneliti bermaksud melakukan penelitian yang berjudul Pengembangan Bahan Ajar Berbasis Website Terhadap Hasil Belajar Matematika Siswa.

Berdasarkan latar belakang tersebut, masalah yang diteliti dalam penelitian ini adalah sebagai berikut

1. Apakah penggunaan media pembelajaran berbasis Website dapat diterapkan di sekolah?

2. Bagaimana Website akan digunakan dalam proses pembelajaran pada materi segi empat dan segitiga?

3. Bagaimana hasil belajar siswa yang menggunakan media Website dalam belajar materi segi empat dan segitiga?

Tujuan penelitian ini adalah sebagai berikut :

1. Mengetahui penggunaan media pembelajaran berbasis e-learning (Website) di sekolah.

2. Menghasilkan produk media pembelajaran "berbasis Website pada materi segi empat dan segitiga.

3. Mengetahui hasil belajar siswa menggunakan Website pada materi segi empat dan segita.

4. Mendapatkan produk multimedia pembelajaran matematika untuk siswa kelas 7 Sekolah Menengah Pertama

5. Mengetahui tingkat kelayakan multimedia pembelajaran matematika siswa kelas 7 Sekolah Menengah Pertama 


\section{LANDASAN TEORI}

\section{Bahan Ajar Berbasis Android}

Bahan ajar atau teaching material terdiri atas dua kata teaching atau mengajar dan material atau bahan. Menurut Chomsin dan Jasmadi (2008: 40), bahan ajar merupakan seperangkat sarana atau alat pembelajaran yang berisikan materi pembelajaran, metode, batasan-batasan dan cara mengevaluasi yang didesain secara sistematis dan menarik dalam rangka mencapai tujuan yang diharapkan, yaitu mencapai kompetensi atau sub-kompetensi dengan segala kompleksitasnya. Menurut Prastowo sebagaimana dikutip oleh Raharjo dan I'anah bahan ajar adalah segala bahan (baik itu informasi, alat, maupun teks) yang disusun secara sistematis yang menampilkan sosok utuh dari kompetensi yang akan dikuasai peserta didik dan digunakan dalam proses pembelajaran dengan tujuan untuk perencanaan dan penelaahan implementasi pembelajaran (Raharjo \& I'anah, 2014: 120). Sedangkan menurut I'anah dalam Raharjo (2014:125) bahan ajar adalah bahan atau materi pelajaran yang disusun secara sistematis baik tertulis maupun tidak tertulis yang digunakan oleh guru dalam pembelajaran di kelas untuk menciptakan suasana/lingkungan pembelajaran yang memungkinkan siswa berminat untuk belajar sehingga mencapai standar kompetensi yang telah ditentukan. Dengan demikian bahan ajar merupakan seperangkat sarana atau alat pembelajaran yang berisikan segala bahan seperti materi, metode dan informasi. Disusun secara sistematis baik tertulis maupun tidak tertulis guna menciptakan suasana atau lingkungan pembelajaran yang menarik sehingga siswa memiliki keinginan lebih untuk belajar dan mencapai standar kompetensi yang telah ditentukan

WWW atau World Wide Web yaitu suatu program yang ditemukan oleh Tim Berners-Lee sekitar pada tahun 1991. Awal mulanya BernersLee berkeinginan menemukan langkah untuk membuat arsip-arsip risetnya. Karenanya, dia meningkatkan suatu system untuk kepentingan pribadi. System itu yaitu program peranti lunak yang dinamakan Equire. Dengan program itu, Berners-Lee sukses membuat jaringan pada beragam arsip hingga mempermudah informasi yang diperlukan. Inilah yang kemudian menjadi awal dari suatu revolusi yang di kenal juga sebagai situs. WWW di kembangkan pertama kalinya di Pusat Riset Fisika Partikel Eropa (CERN), Jenewa, Swiss. Pada tahun 1989 Berners-lee membuat proposal untuk proyek pembuatan hypertext dengan cara global, kemudian pada bulan Oktober 1990, 'World Wide Web' sudah dapat digerakkan dalam lingkungan CERN.

Layanan yang ada yaitu seperti search engine, berita, pooling, beragam jenis rubrik serta sarana seperti SMS dan chat room. Yang berbentuk personal dan dapat berbentuk personal diary serta kalender, akun e-mail bahkan juga personal situs. Situs Portal vertical bahkan juga dapat berbentuk eksklusif serta hanya menghadirkan informasi yang dikehendaki komunitasnya. Umpamanya web 
yang berbentuk religius seperti scientology, tetapi mungkin demikian sebaliknya berbentuk terbuka walau mengulas hal khusus seperti toko buku amazon

\section{Yuhefizar}

mengungkapkan pengertian website. Website atau disebut web blog adalah keseluruhan halaman-halaman web yang terdapat dari sebuah domain yang di dalamnya mengandung informasi. Sebuah website biasanya dibangun atas banyak halaman web yang saling berhubungan. Hubungan antara satu halaman web dengan halaman web yang lain disebut dengan hyperlink. Sedangkan teks yang dijadikan media penghubung disebut hypertext. Sebuah website dapat diakses melalui browser, yaitu perangkat lunak untuk mengakses halaman-halaman web, seperti internet explorer, mozilla firefox, opera, safari dan chrome..

\section{Hasil Belajar}

1. Teori Belajar

Hamalik (2008: 20) mengemukakan bahwa belajar merupakan suatu proses, dan bukan hasil yang hendak dicapai semata. Proses itu sendiri berlangsung melalui serangkaian pengalaman, sehingga terjadi modifikasi pada tingkah laku yang telah dimiliki sebelumnya. Jadi berdasarkan proses (sebagai alat atau means) akan tetapi tujuan (ends), sesuatu yang dikehendaki dalam pendidikan.

2. Motivasi Belajar

Menurut

(2011:75)

Sardiman motivasi sebagai serangkaian usaha sehingga seseorang mau dan ingin melakukan sesuatu, dan apabila ia tidak suka, maka akan berusaha untuk meniadakan atau mengelakkan perasaan suka itu. Sedangkan menurut Syaodih (2006: 61) menyatakan motivasi merupakan kekuatan yang menjadi pendorong individu dalam melakukan sesuatu. Agar tenaga pendorong pada diri seseorang cukup besar maka diperlukan motivasi dari luar. Pada diri siswa motivasi dapat berasal dari guru, teman, orang tua, buku-buku dan lingkungan.

3. Definisi Hasil Belajar

Menurut Hamalik (2008: 155), hasil belajar didefinisikan sebagai "suatu proses terjadinya perubahan tingkah laku pada diri siswa, yang dapat diamati dan diukur dalam bentuk perubahan pengetahuan sikap dan keterampilan". Merujuk pemikiran Gagne dalam Supriono (2012: 5) berpendapat, hasil belajar berupa:

a) Informasi verbal yaitu kapabilitas mengungkapkan pengetahuan dalam bentuk bahasa, baik lisan maupun tertulis.

b) Keterampilan intelektual yaitu kemampuan mempresentasikan konsep dan lambang. Keterampilan intelektual terdiri dari kemampuan 
mengategorisasi,

kemampuan analitissintetis fakta-konsep dan mengembangkan prinsip-prinsip

keilmuan.

c) Strategi kognitif yaitu kecakapan

menyalurkan dan mengarahkan aktifitas kognitifnya sendiri. Kemampuan ini meliputi penggunaan konsep dan kaidah dalam memecahkan masalah.

d) Keterampilan motorik yaitu kemampuan melakukan

serangkaian gerak jasmani dalam urusan dan koordinasi, sehingga terwujud otomatisme gerak jasmani.

e) Sikap adalah kemampuan menerima atau menolak objek berdasarkan penilaian terhadap objek tersebut. Sikap berupa kemampuan menginternalisasi dan eksternalisasi nilainilai. Sikap merupakan kemampuan

menjadikan nilai-nilai sebagai standar prilaku.

Hasil belajar

merupakan hasil

kegiatan belajar siswa yang menggambarkan keterampilan atau penguasaan siswa terhadap bahan ajar. Hasil belajar biasanya dinyatakan dalam nilai tes atau angka nilai yang diberikan oleh guru. Tes yang digunakan untuk menentukan hasil belajar merupakan suatu alat untuk mengukur aspekaspek tertentu dari siswa. (Dimyati dan Mudjiono, 2009 : 256-259).

Dari beberapa uraian di atas dapat disimpulkan bahwa hasil belajar merupakan terdapatnya perubahan tingkah laku dan sikap yang dialami siswa setelah melakukan proses pemebelajaran serta mampu menyampaikan informasi dengan bahasa, lisan maupun tulisan dan juga biasanya dinyatakan dalam niali tes atau angka nilai yang diberikan oleh guru.

Bloom membagi hasil belajar dalam tiga ranah, yakni ranah kognitif, ranah afektif dan ranah psikomotoris.

a. Ranah Kognitif

Ranah ini berkenaan dengan hasil belajar intelektual yang terdiri dari enam aspek, yakni pengetahuan (knowledge), pemahaman, aplikasi, analisis, sintesis dan evaluasi.

a. Ranah Afektif

Ranah afektif berkenaan dengan sikap dan nilai. Tipe hasil belajar afektif tampak pada siswa dalam berbagai tingkah laku seperti perhatiannya terhadap pelajaran, disiplin, motivasi belajar, mengahargai guru, 
kebiasaan belajar, dan hubungan sosial.

b. Ranah Psikomotoris

\begin{tabular}{lr}
\multicolumn{1}{c}{ Hasil } & $\begin{array}{r}\text { belajar } \\
\text { tampak }\end{array}$ \\
psikomotoris & bentuk \\
dalam & (skill) dan \\
keterampilan & bertindak \\
kemampuan & bemaindu.
\end{tabular}

\section{METODE PENELITIAN}

Penelitian menggunakan model penelitian yang diadaptasi dari model pengembangan ADDIE (Analysis, Design, Develop, Implement, dan Evaluate) dengan pendekatan jenis penlitian $\mathrm{R} \& \mathrm{D}$ (Research and Development). Model ADDIE mulai ada pada tahun 1990an yang dikembangkan oleh Dick dan Carry yang digunakan untuk merancang sistem pembelajaran (Mulyatiningsih, 2012). Model ini menggunakan 5 tahap yaitu tahap Analysis, Design, Development, Implementation, and Evalution.

Populasi adalah keseluruhan subjek penelitian. Penelitian ini dilaksanakan di SMP Negeri 1 Krangkeng Kabupaten Indramayu semester II di kelas VII dengan jumlah 214 siswa. Sampel adalah sebagian atau wakil populasi yang akan diteliti. Sedangakan dalam penelitian ini yang menjadi sampel adalah kelas VIII-E dengan jumlah siswa 30 siswa (kelas eksperimen) dan kelas VIII-F dengan jumlah 30 siswa (kelas kontrol). Teknik yang digunakan untuk mengumpulkan sampel yaitu Purposive Sampling, karena sampel diambil berdasarkan tujuan atau pertimbangan tertentu. Adapun yang menjadi pertimbangan peneliti adalah informasi dari guru matematika. Jadi sampel yang diambil berjumlah 60 siswa.

\section{Teknik Analisis Data}

\section{Data Kualitatif}

Data kualitatif dari penelitian dan pengembangan diperoleh dari hasil angket respon siswa terhadap bahan ajar matematika berbasis Android yang dikembangkan. Angket yang digunakan adalah angket skala likert, dengan 20 pernyataan dan 5 kriteria jawaban yaitu sangat setuju(SS), setuju(S), raguragu(RR), tidak setuju(TS) dan sangat tidak setuju(STS).

Tabel 1 : Skala Likert angket respon siswa

\begin{tabular}{|c|c|c|c|}
\hline \multicolumn{2}{|c|}{ Pernyataan Positif } & \multicolumn{2}{|c|}{$\begin{array}{c}\text { Pernyataan } \\
\text { Negatif }\end{array}$} \\
\hline Pernyataan & Skor & Pernyataan & Skor \\
\hline Sangat & 5 & Sangat & 1 \\
\hline Setuju (SS) & & Setuju (SS) & \\
\hline Sangat & 4 & Sangat & 2 \\
\hline Setuju (SS) & & Setuju (SS) & \\
\hline $\begin{array}{l}\text { Ragu-ragu } \\
(\mathrm{RG})\end{array}$ & 3 & $\begin{array}{l}\text { Ragu-ragu } \\
(\mathrm{RG})\end{array}$ & 3 \\
\hline $\begin{array}{l}\text { Tidak } \\
\text { setuju (TS) }\end{array}$ & 2 & $\begin{array}{l}\text { Tidak } \\
\text { setuju (TS) }\end{array}$ & 4 \\
\hline $\begin{array}{l}\text { Sangat } \\
\text { tidak setuju } \\
\text { (STS) }\end{array}$ & 1 & $\begin{array}{l}\text { Sangat } \\
\text { tidak } \\
\text { setuju } \\
\text { (STS) }\end{array}$ & 5 \\
\hline
\end{tabular}

\section{Data Kuantitatif}

Pengolahan data secara kuantitatif menggunakan instrumen tes, sehingga perlu diadakan pengujian terhadap instrumen yang mencakup: validitas, reliabilitas, uji daya beda, uji tingkat kesukaran dan uji n-gain.

Uji n-gain digunakan untuk mengetahui berapa besar peningkatan hasil belajar siswa pada kelas kontrol dan kelas eksperimen. Peneliti menggunakan rumus n-gain 
normal menurut (Baharuddin, 2014):

$<g>$

$=\frac{\text { Skor postest }- \text { skor pretest }}{\text { Skor maksimum }- \text { skor pretest }}$

Hasil perhitungan diintepretasikan dengan menggunakan indeks gain $<$ g> sebagai berikut :

Tabel 2 Kriteria $N$ - Gain

\begin{tabular}{|c|c|}
\hline $\begin{array}{c}\text { Indeks } \\
\text { gain }\end{array}$ & Kriteria \\
\hline$g \leq 0,30$ & Rendah \\
\hline $\begin{array}{c}0,30 \leq g \\
\leq 0,70\end{array}$ & Sedang \\
\hline$g \geq 0,70$ & Tinggi \\
\hline
\end{tabular}

\section{Uji Prasyarat Analisis}

Uji prasyarat analisis yang digunakan dalam penelitian ini adalah uji normalitas dan uji homogenitas.

\section{Uji Hipotesis}

Setelah data tergolong berdistribusi normal dan homogen, selanjutnya yaitu melakukan uji hipotesis yaitu menggunakan uji $\mathrm{t}$ atau uji perbandingan dua variabel.

\section{HASIL DAN PEMBAHASAN}

Penelitian dilakukan dari bulan Januari sampai bulan Maret di SMP N 1 Krangkeng Kabupaten Indramayu. Produk Bahan ajar yang dihasilkan dalam penelitian ini adalah sebuah Website yaitu dengan alamat web www.belajarmatematika.id yang telah melalui proses validasi oleh tim ahli media dan ahli materi, dan telah diuji cobakan ke siswa SMP N 1 Krangkeng Kabupaten Indramayu khususnya kelas VIII-E sebagai kelas eksperimen. Di dalam aplikasi ini terdapat dari mulai standar kompetensi, kompetensi dasar, indikator, kumpulan materi tentang segi empat dan segitiga serta kuis sebagai media tes, serta beberapa fitur lainnya seperti video interaktif, dan website ini juga bisa diupdate sesuai dengan kebutuhan. Aplikasi ini hanya di jalankan secara online.

Pengembangan bahan ajar berbasis Android ini merupakan adaptasi dan dimodifikasi dari langkah-langkah penelitian dan pengembangan model ADDIE yaitu dengan tahapan: Analysis (analisis), Design (desain), Development (pengembangan), Implementation (implementasi), Evaluation (evaluasi).

Pada tahapan pembuatan sistem, penulis menggunakan metode prototipe dalam web engineering untuk System Development Live Cycle (SDLC). Metode ini dilakukan dengan lima tahapan, yaitu :

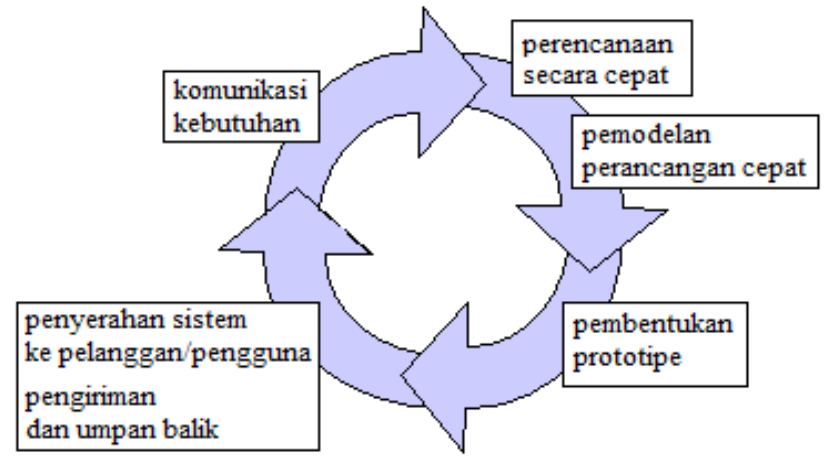

$$
\begin{aligned}
& \text { Gambar 1 Metode } \\
& \text { prototipe dalam SDLC }
\end{aligned}
$$

1) Komunikasi kebutuhan

Pada tahapan ini penulis mengidentifikasi masalah yang ada, kemudian melakukan komunikasi dengan stakeholder (pemangku kepentingan) dalam hal ini adalah 
"Nama Sekolah" untuk mendapatkan informasi berupa spesifikasi kebutuhan seperti apa saja yang diinginkan untuk diterapkan ke dalam sistem yang ingin dibangun berserta output yang diharapkan. Dalam hal ini komunikasi yang efektif sesungguhnya merupakan aktivitas paling menantang yang selalu dan harus kira hadapi. Berdasarkan konteks efektivitas dari hasil yang didapatkan, komunikasi yang terbaik adalah komunikasi yang dilakukan secara langsung atau tatap muka.

2) Perencanaan

Aktivitas

merupakan sejumlah praktik menejemen dan teknis yang memungkinkan penulis untuk mendefinisikan suatu peta jalan (road map). Penulis harus menemukan tujuan-tujuan yang bersifat strategik dan taktis, perencanaan yang berlebihan akan memboroskan waktu dan tidak memungkinkan adanya perubahanperubahan didalam peroyek tersebut, tetapi kurangnya perencanaan juga bisa mengakibatkan kekacauan, maka pada tahap ini harus bisa memanfaatkan waktu sebaik mungkin.

3) Pemodelan

Model dibuat untuk mendapatkan pemahaman yang lebih baik tentang entitas nyata yang akan dibuat. Saat entitas tersebut merupakan sesuatu yang bersifat fisik (misalnya bangunan, pesawat terbang, mesin) kita bisa membuat model yang identik dalam ukuran dan bentuk teteapi dalam skala yang jauh lebih kecil. Meskipun demikian, saat entitas yang akan dibuat adalah suatu perangkat lunak, model kita harus menggunakn bentuk yang berbeda. Model itu harus dapat merepresentasikan informasi yang akan di trasnformasi oleh perangkat lunak, fitur-fitur yang dikehendaki oleh pengguna serta memperesentasikan perilaku sistem saat transformasi itu benar-benar terjadi.

4) Konstruksi (Pembentukan Prototipe)

Pada tahap ini penulis membuat kode untuk membangung sistem berdasarkan informasi yang telah didapat di tahap komunikasi kebutuhan, kemudian menguji sistem yang dibuat untuk diajukan kepada stakeholder (pemangku kepentingan) dalam hal ini adalah "Nama Sekolah".

5) Penyerahan

Aktivitas penyerahan perangkat lunak kepada pelanggan memiliki 3 aksi penting, yaitu pengiriman, dukungan, dan umpan balik. Perangkat lunak akan diserahkan beberapa kali sebelum akhirnya perangkat lunak lengkap dihasilkan. Perangkat lunak yang dikirimkan akan memberi keuntungan kepada pengguna, tetapi pengguna juga akan memberikan umpan balik dari pengalaman menggunakan perangkat lunak tersebut yang akan sangat bermanfaat bagi programmer.

Pada proses perancangan sistem ini mencakup use case diagram dan activity diagram untuk mempermudah dalam pemahaman perancangan supaya hasil yang didapat adalah sistem yang baik, hal ini merupakan bagian dari tahap pemodelan. Sistem yang dirancang diuraikan menjadi beberapa bagian yang dapat membentuk sistem tersebut menjadi satu kesatuan komponen

Hasil Pre-test dan Post-test kelas eksperimen 
a. Pre-test

Data pretest pada kelas eksperimen merupakan data awal yang diambil untuk mengetahui kemampuan awal siswa sebelum diberikan perlakuan. Pengambilan data dialkukan dengan memberikan tes berupa soal pilihan ganda sebanyak 20 soal kepada siswa. Dari pretest pada kelas eksperimen tersebut diperoleh skor tertinggi 50, skor terendah 15, dan data rata-rata 29,16 dengan kriteria kurang, sedangkan varians sebesar 88,074 dan standar deviasi sebesar 9,384.

b. Post-test

Data postest pada kelas eksperimen merupakan data diperoleh dari siswa setelah diberikan perlakuan. Dari postest pada kelas eksperimen tersebut diperoleh skor tertinggi 90, skor terendah 55, dan rata - rata 77 dengan kriteria baik. Sedangkan varians sebesar 44,137 dan standar deviasi sebesar 6,643.

Berdasarkan perhitungan hasil pre-test dan post-test di atas, dapat disimpulkan bahwa adanya perbedaan hasil belajar siswa setelah menggunakan website sebagai bahan ajar dalam proses pembelajaran.

\section{Analisis Hasil Penelitian}

1) Uji Normalitas

Uji normalitas dilakukan dengan menggunakan uji Kolmogorov- Smirnov ${ }^{a}$ dan Saphiro-Wilk. Dasar pengambilan keputusan dalam pengujian normalitas data pre-test dan posttest kelas kontrol dan kelas eksperimen dengan menggunakan uji Kolmogorov-Smirnov ${ }^{a}$ dan Saphiro Wilk yaitu:

- Jika nilai sig. atau signifikansi atau nilai probabilitas $>0,05$, maka data berdistribusi normal.

- Jika nilai sig. atau signifikansi atau nilai probabilitas $<0,05$, maka data berdistribusi tidak normal.

\section{Tests of Normality}

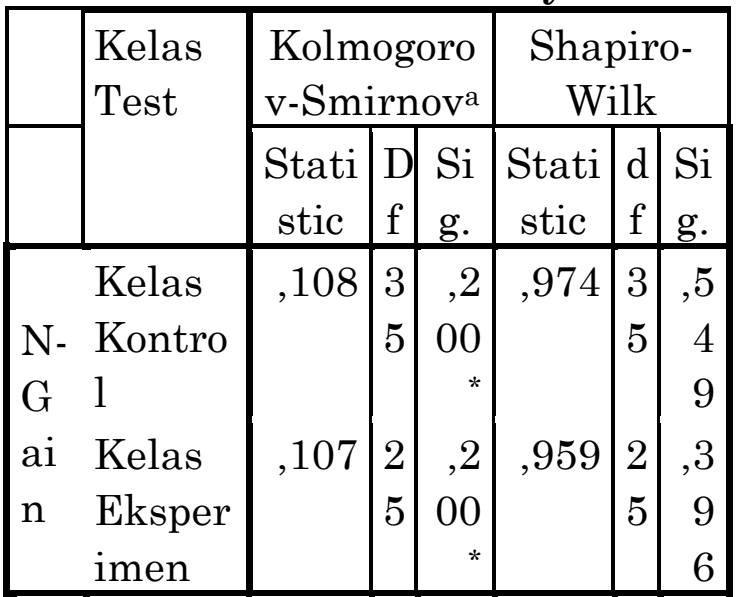

*. This is a lower bound of the true significance.

a. Lilliefors Significance Correction

Hasil uji normalitas pada tabel test of normality di atas, data gain kontrol dan gain eksperimen menunjukkan nilai signifikan pada uji Kolmogorov-Smirnov masingmasing sebesar 0,200 dan 0,200, serta menurut uji Shapiro-wilk menunjukkan nilai signifikan masingmasing sebesar 0,549 dan 0,396 . Karena nilai signifikan dari kedua uji tersebut berada di atas 0,05, data gain kelas kontrol dan data gain kelas eksperimen berdistribusi normal. 
2) Uji Homogenitas

\section{Test of Homogeneity of Variance}

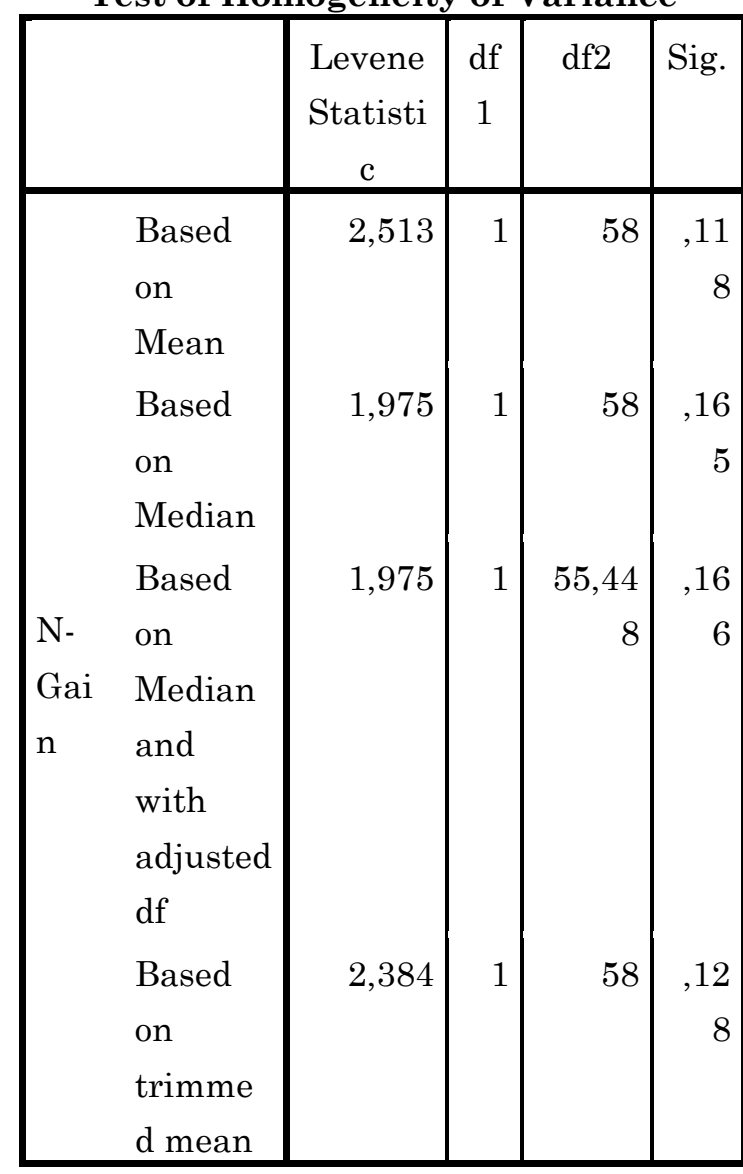

Tabel hasil uji homogenitas Lavene Test di atas, menunjukan tingkat signifikan atau nilai probabilitas berada di atas 0,05 . Oleh karena probabilitas $>0,05$, data gain kontrol dan gain eksperimen adalah homogen.

3) Uji Independent $t$ Test

Dari uji normalitas dan homogenitas didapt bahwa data kelas eksperimen dan kelas kontrol normal dan homogenitas. Sedangkan uji hipotesis dilakukan dengan uji parameterik yaitu menggunnkan uji t-2 sampel saling bebas atau Independent Sampel T-test.

Dengan bantuan SPSS diperoleh thitung sebesar 6,331 dengan menggunakan taraf singnifikasi sebesar $5 \%$ diperoleh nilai tabel sebesar 2,000. Nilai $t_{\text {tabel }}$ tersebut diperoleh dari program excel dengan cara $=\operatorname{tinv}(0,05 ; 60)$ lalu enter. Sehingga nilai thitung $>$ tabel yang artinya $\mathrm{H}_{0}$ ditolak. Karena $\mathrm{H}_{\mathrm{o}}$ ditolak maka dapat diartikan bahwa peningkatan haisl belajar siswa yang menggunakan bahan ajar berbasis website lebih tinggi dibandingkan dengan siswa yang menggunakan bahan ajar cetak. Dari tabel deskriptif juga terlihat bahwa rata - rata skor gain siswa yang menggunakan bahan ajar berbasi website sebesar 0,67. dan rata - rata skor gain siswa yang menggunakan bahan ajar cetak sebesar 0,52 . Hal ini menunjukan bahwa peningkatan hasil belajar yang menggunakan bahan ajar berbasis website lebih tinggi dibandingkan dengan siswa yang tidak menggunakan bahan ajar berbasi website.

4) Respon Siswa terhadap Bahan Ajar Berbasis Android Menggunakan Aplikasi "Bulok Geometry".

Peneliti memperoleh data dari penyebaran angket yang diberikan pada kelas eksperimen yang pembelajarannya menngunakan website. Penyebaran angket ini 
bertujuan untuk mengetahui respon terhadap bahan ajar tersebut. Adapun respon siswa dilihat dari tiga aspek yaitu aspek pemahaman, aspek tampilan dan kualitas interaksi dan aspek minat siswa dan kemenarika media . Dari hasil analisis diperoleh respon siswa aspek pemahaman $86 \%$, aspek tampilan dan kualitas interaksi $82 \%$ dan aspek minat siswa dan kemenarikan media sebesar $87 \%$. Sehingga dapat diketahui rata-rata persentase respon siswa terhadap bahan ajar berbasis website adalah sebesar $85,08 \%$ dengan kriteria Kuat.

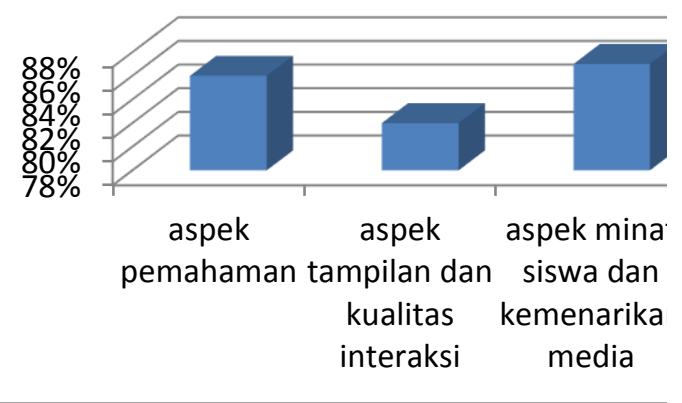

\section{Pembahasan}

Dari hasil penelitian yang telah dilakukan, akhirnya peneliti mendapatkan hasil dari penemuan masalah yang telah dirumuskan sebelumnya. Bahan ajar berbasi website yang telah divalidasi oleh dua ahli media dan dua ahli materi pembelajaran. Ahli media yang melakukan peilaian bahan ajar berbasis website ini adalah dosen IAIN Syekh Nurjati Cirebon yakni Bapak Saluky sebagai ahli media 1 dan Bapak Ayatullah Kumaeni S.E,I dari guru komputer sekolah SMPN 1 KRANGKENG sebagai ahli media 2.
Sedangkan untuk ahli materi yang melakukan penilaian bahan ajar berbasis website ini adalah dosen IAIN Syekh Nurjati Cirebon Bapak Arif Abdulhaq sebagai ahli materi 1 dan Bapak Atma Negara S.Pd guru matematika sekolah SMPN 1 KRANGKENG sebagai ahli materi 2. Berdasarkan hasil validasi terhadap media yang diperoleh dari dua ahli media dan dua ahli materi diperoleh prosentase sebesar 79\% (Baik) untuk kualitas pembelajaran dan $76 \%$ (Baik) untuk kualitas materi. Sedangkan dari segi media diperoleh prosentase sebesar 78\% (Baik) untuk kualitas tampilan, prosentase sebasar 92\% (Sangat Baik) untuk kualitas isi, prosentase sebesar 77,5\% (Baik) untuk kualitas bahasa, prosentase sebesar 90\% (Sangat Baik) untuk kulitas interaktivitas. Sehingga secara keseluruhan hasil dari ahli materi menunjukkan prosentase $77 \%$ dengan kriteria baik sedangkan hasil ahli media menunjukkan prosentase sebesar 85,5\% dengan kriteria sangat baik. Hal ini menunjukkan bahwa media/bahan ajar berbasis website sudah layak digunakan meskipun ada sedikit revisi, komentarm dan saran dari dosen pembimbing, ahli materi dan ahli media pembelajaran.

Dari hasil penelitian yang telah dilakukan di SMPN 1 KRANGKENG, peneliti dapat mengetahui bahwa rata - rata hasil belajar yang menggunakan bahan ajar berbasis website sebesar 77 sedangkan rata - rata hasil belajar siswa yang tidak menggunakan bahan aja berbasis website sebesar 67,33 dapat dilihat bahwa rata - rata hasil belajar siswa yang menggunakan bahan ajar berbasis website sudah memenuhi KKM (Kriteria Ketuntasan Minimal) yang 
ditetapkan adalah 75. Pada pengjian efektivitas produk menggunakan perhitungan dari hasil analisis uji Independent T-test diperoleh nilai thitung sebesar 6,331 Dengan menggunakan taraf signifikansi 5\% diperoleh niali tabel sebesar 2,000. Nilai $t_{\text {tabel }}$ tersebut diperoleh dari program excel dengan cara =tinv (0,05:60) lalu enter. Sehingga nilai $\mathrm{t}_{\text {tabel }}>\mathrm{t}_{\text {hitung }}$ yang artinya $\mathrm{H}_{0}$ ditolak. Ini artinya bahwa peningkatan hasil belajar siswa yang menggunakan bahan ajar berbasis website lebih efektif dibandingkan siswa yang tidak menggunakan bahan ajar berbasis website.

Hal ini senada dengan pendapat Mustikasari dalam Yohana (2011:17) yang menyatakan bahwa beberapa manfaat dari penggunaan media dalam pembelajaran diantaranya yaitu proses pembelajaran dapat lebbih jelas dan menarik, meningkatkan kualitas hasil belajar siswa, dan media dapat menumbuhkan sikap positif siswa terhadap materi dan proses belajar. Dengan proses pembelajaran yang lebih jelas dan menarik, maka akan menumbuhkan rasa senang bagi siswa dalam proses pembelajaran matematika. Sehingga secara tidak langsung akan menumbuhkan sikap positif siswa terhadap matematika khususnya pada materi yang sedang dipelajari. Sikap positif sangat dibutuhkan dalam proses pembelajaran karena sikap positif akan menggerakkan siswa untuk lebih giat dalam belajar. Dengan demikian, proses pembelajaran dapat meningkat yang berdampak pula pada peningkatan kualitas pembelajaran. Sehingga dengan meningkatnya kualitas pembelajaran, secara tidak langsung akan terjadi pula peningkatan pada hasil belajar.

Selain hasil belajar, dari penelitian ini diperoleh respon siswa terhadap pembelajaran matematika yang menggunakan website. Rata rata hasil respon siswa prosentase sebesar 85,08 \% dengan kriteria sangat kuat. Secara rinci kriteria tersebut diperoleh dari segi aspek pemahaman sebesar $86 \%$ dengan kriteria sangat kuat, dari segi aspek tampilan dan kualitas interkasi prosentase sebesar $82 \%$ dengan kriteria sangat kuat, dan dari segi aspek minat siswa dan kemenarikan media prosentase sebesar $87 \%$ dengan kriteria sangat kuat Hal ini berarti siswa memberikan respon positif terhadap pembelajaran matematika menggunakan bahan ajar berbasis website..

\section{KESIMPULAN}

Berdasarkan hasil penelitian dan kajian data pada BAB IV tentang Pengembangan Bahan Ajar Berbasis Website dapat disimpulkan sebagai berikut:

1. Pengembangan bahan ajar ini menggunakan model ADDIE yang terdiri dari lima tahapan yaitu Analysis, Design, Development, Implementation, dan Evaluation. Pada tahap Analysis dilakukan analisis kebutuhan dan dihasilkan analisis kebutuhan kurikulum dan analisis kebutuhan akademis dan non akademis. Pada tahap Design dibuat naskah naskah media (storyboard) dan mengumpulkan semua bahan yang dibbutuhkan sesuai dengan storyboard dan menyiapkan semua software yang 
dibutuhkan utuk membuat website. Tahap Development diawali dengan membangun media yang akan dikembangkan sesuai dengan storyboard yang telah dibuat kemudian melakukan evaluasi terhadap media yang sedang dikembangkan oleh ahli materi dan ahli media, setelah mendapatkan masukan dan saran dari ahli media dan ahli materi kemudian melakukan revisi media. Tahap Implementation yaitu dengan mengimplementasikan media yang telah dibuat. Pada tahap ini juga dilakukan dengan tes berupa pretest dan postest kepada kelas eksperimen dan ke las kontrol. Selain itu juga dilakukan penyebaran angket pada kelas eksperimen untuk mengetahui respon terhadap media yang sedang dikembangkan. Tahap terakhir dari ADDIE yaitu Evaluation, pada tahap ini dilakukan analisis data dari hasil tes belajar siswa dan hasil angket yang telah disebarkan.

2. Uji keefektifan produk menggunakan dari hasil analisis Uji Independent T - test diperoleh nilai sebesar $t_{\text {hitung }}$ sebesar 6,331. Dengan menggunakan taraf signifikansi sebesar 5\% diperoleh nilai $t_{\text {tabel }}$ sebesar 2,000. Nilai $t_{\text {tabel }}$ tersebut diperoleh dari program excel dengan cara $=\operatorname{tinv}(0,05 ; 60)$ lalu enter. Karena 6,331 > 2,000 maka $H_{0}$ ditolak. Ini artinya bahwa peningkatan hasil belajar siswa menggunakan bahan ajar berbasis website lebih efektif dibandingkan siswa yang tidak menggunakan bahan ajar berbasis website.

3. Rata - rata respon siswa terhadap media yang dibuat mendapatkan skor sebesar 86\% dengan kriteria sangat kuat untuk aspek pemahaman, $82 \%$ dengan kriteria kuat untuk aspek tampilan dan kualitas interaksi, dan 87\% dengan kriteria kuat untuk aspek minat siswa dan kemenarikan media. Sehingga dari respon siswa terhadap media berdasarkan keseluruhan kriteria, rata - rata skornya sebesar $86,08 \%$ dengan kriteria sangat kuat..

\section{DAFTAR PUSTAKA}

Baharuddin, Ilham. 2014.

Efektivitas Penggunaan Media

Video Tutorial Sebagai

Pendukung Pembelajaran

Matematika Terhadap Minat

dan Hasil Belajar Peserta

Ddidik Sma Negeri 1 Bajo

Kabupaten Luwu Sulawesi

Selatan. Volume 2. Nomer 2.

ISSN: 2339-0794.

Dimyati \& Mudjiono. (2006). Belajar dan Pembelajaran. Jakarta:

Rineka Cipta..

Hamalik, Oemar. (2008).

Perencanaan Pengajaran

Berdasarkan Pendekatan

Sistem. Jakarta: Bumi Aksara.

https://kominfo.go.id/content/detail/4

286/pengguna-internet-

indonesia-nomor-enam-

dunia/0/sorotan_media diakses pada tanggal $01-12-2016$.

Muntoha, dkk. (2010).

Pengembangan sistem evaluasi pembelajaran berbasis web (web

based learning assessment system). Jurnal Ilmiah Jurusan

Fisika Kampus Unnes Sekaran

Gunungpati Gd D7 Lt 2. 195199.

Mulyatiningsih, Endang. (2013).

Metode Penelitian Terapan 
Bidang Pendidikan. Bandung:

Alfabeta.

Baharuddin, I. (2014). Efektivitas

Penggunaan Media Video

Tutorial Sebagai Pendukung

Pembelajaran Matematika

Terhadap Minat dan Hasil

Belajar Peserta Didik SMA

Negeri 1 Bajo Kabupaten Luwu

Sulawesi Selatan., 2.

Sardiman. (2011). Interaksi dan

Motivasi Belajar

Mengajar.Yogyakarta: Raja

Grafindo Persada

Sanjaya, Wina.(2011). Strategi

Pembelajaran Berorientasi

Standar Proses

Pendidikan.Jakarta : Kencana

Prenada Media.

Syaodih, Nana. (2006). Landasan

Psikologi Proses Pendidikan.

Bandung: Rosdakarya

Suprijono, Agus. (2012). Cooperative

Learning Teori dan Aplikasi

PAIKEM. Yogyakarta: Pustaka

Belajar
Raharjo, H. (2014). Pengembangan bahan ajar berbasis komputer dalam pembelajaran matematika pada pokok bahasan kubus dan balok. EDUMA: Mathematics

Education Learning and Teaching, 3(2)

Umar. (2013). Media Pendidikan: Peran dan Fungsinya dalam Pembelajaran. Jurnal Tarbawiyah Volume 10 Nomor 2 Yuhefizar. (2011). Cara Mudah Membangun Website Berbasis CMS Joomla.Jakarta: PT. Elex Media Komputindo

Yohana, Analisa. (2011) . Studi Tentang Media Pembelajaran yang Digunakan Pada Mata Pelajaran Seni Budaya Bidang Seni Rupa Di SMP Negeri 1 Probolinggo. Skripsi Malang: Universitas Negeri Malang 